\title{
'Autopsychography' as a Form of Self-Narrative Inquiry
}

Yanyue Yuan and Richard Hickman

Faculty of Education, University of Cambridge, Cambridge, UK

Corresponding Author: Yanyue Yuan, University of Cambridge Faculty of Education, 184

Hills Rd, Cambridge, CB2 8PQ. Mobile: 0086 13918588280. E-mail:

dreamingselena@icloud.com 


\section{'Autopsychography' as a Form of Self-Narrative Inquiry}

In this paper, we propose 'autopsychography' as a form of self-narrative inquiry. Autopsychography seeks to track the shaping of creative paths when reflecting on lived experience as opposed to simply reporting what happened. We illustrate four major theoretical implications underpinning this concept: its rootedness in humanistic psychology that frames the human subject as the 'whole person'; its commitment to an ethic of caring; its emphasis on 'change' and 'growth', core to educative experience; and its arts-informed features. We situate our discussions of autopsychography in the context of self-narrative approaches and we underscore its distinctiveness through comparisons with autoethnography as an already well-recognised methodology.

We then present an autopsychographic study into Yanyue's experience after submitting the softbound copy of her PhD thesis, in which she experimented with an 'oral diary' and the use of 'found poetry' as ways of presenting data.

Keywords: autopsychography; self-narrative; oral diary; post-submission experience; found poetry 


\section{'Autopsychography' as a Form of Self-Narrative Inquiry}

\section{'Self' in Self-Narrative Inquiry}

With the surge of self-narrative inquiry in social sciences, a number of approaches have been developed and applied in qualitative education research. Similar to narrative research, self-narrative 'is an umbrella term that covers a large and diverse range of approaches' (Mishler, 1999, p. xv). We want to underscore the diversity within self-narrative inquiry, especially the various connotations of 'self' and the extent of researchers' involvement in shaping the stories of 'self'.

Autoethnography has been widely applied since the beginning of the twenty-first century, often as a methodology that uses "personal experience to examine and/or critique cultural experience' (Jones, Adams, \& Ellis, 2013, p. 22). When 'autoethnography' first appeared in the late twentieth century, however, it mainly referred to ethnography of one's own cultural group. The scope of autoethnography has been gradually widened into 'a form of self-narrative that places the self within a social context' (Reed-Danahay, 1997, p. 9). As illustrated in Figure 1, the two forms of autoethnography mainly differ in their interpretation of the three axes of the term: auto- (self), -ethno- (the cultural link) and -graphy (the application of a research process). The first type of autoethnography emphasises on 'auto-' whereas the second underscores '-ethno-'. In view with our focus on self-narrative approaches in education research, our discussion of autoethnography in this paper mainly refers to the first form of autoethnography. 


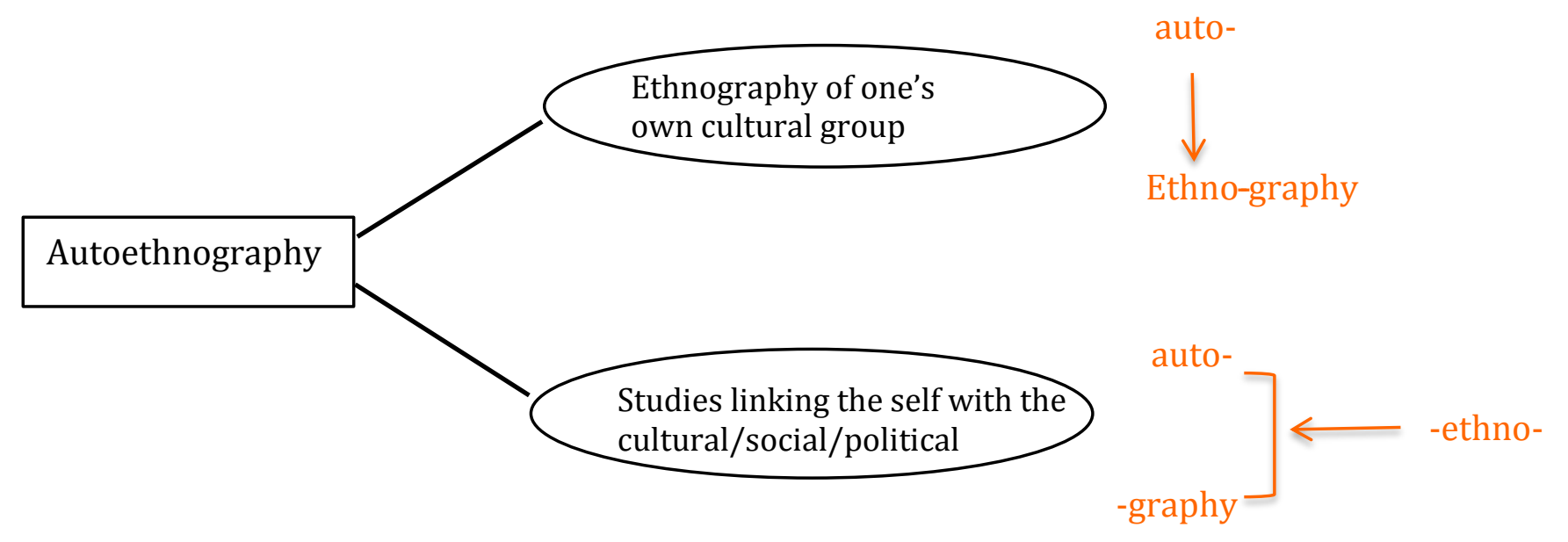

Figure 1. Two Forms of Autoethnography

In addition to autoethnography, we have identified three other self-narrative approaches in qualitative education research: life story (Atkinson, 1998), neo-narrative (Alexander, 1992; Stewart, 2008), and self-portraiture (Hickman, 2013). By sketching out their main characteristics, we will outline the underlying considerations behind the methodological frameworks of these self-narrative approaches.

In psychology, methods of collecting and editing oral accounts have evolved into the life story approach, informed by the 'individual psychology', which focuses on how 'people conceive themselves in terms of stories' (Polkinghorne, 1988, p. 107). The life story approach as method is now widely used to capture life-as-a-whole from what the person chooses to tell. During life story interviews, respondents talk about 'the life he or she has lived, ... what is remembered of it, and what [he or she] wants others to know of it' (Atkinson, 1998, p. 8).

While the life story approach mainly relies on oral forms of story, 'neo-narrative' and 'self-portraiture' can sometimes include other forms of 'stories'. 'Neo-narrative', a term coined by Alexander (1992), stresses the researchers' effort of reframing and reorganising 
stories told by participants. In Alexander and Galbraith's (1997) study, the student teachers were asked to write their stories as responses to the questions posed by researchers, who then edited the documents to present a coherent piece of writing. Alexander (1992) believes that neo-narrative allows 'a story [to] be more representative than the one it replaces' (pp. 77-78). In contrast, Hickman (2011) employs self-portraiture to present the stories of ten art teachers, and he uses the term 'self-portrait' metaphorically 'to explore in writing the distinctive things that characterize the author' (p. 18). Unlike neo-narrative, the accounts written by the respondents are displayed verbatim and Hickman only collates the whole documents and provides his responses and observations in separate sections.

The above are just a brief description of three forms of self-narrative approaches. Despite their differences in history, disciplinary influences, and specific methods, we believe that what sets them apart at a more fundamental level is their different designation of 'self' and the role of researchers in shaping the stories. We thus divide self-narrative approaches into three broad categories:

(1) Researchers reporting stories about participants' selves (e.g., life story, neo-narrative);

(2) Researchers creating narratives about their own personal experience (e.g., autoethnography, self-portraiture);

(3) Researchers synthesising the stories created by themselves and participants (e.g., autoethnography, self-portraiture).

Our classification, however, should be understood with a framework that distinguishes 'the researcher' from 'the participants'. We are aware that other modes of selfnarrative inquiry may even eliminate the necessity of discerning and differentiating the different roles. In the above three categories, we have called attention to the two possible aspects of 'self': 'self' as the protagonist of the story and/or 'self' as the reporter/storyteller. In the third form of self-narrative, the multidimensionality of the 'self' demands the 
researcher to attend to multiple roles: as the initiator, the storyteller, the protagonist, the writer, the editor and the reporter. The second form of self-narrative brings equal, if not more, challenges, when the researcher turns to his/her own experience as the main research subject. The rationale and feasibility of the second form of self-narrative have been discussed variously (Abbs, 1974; Jones, Adams, \& Ellis, 2013; Leggo, 2008), and consensus has been reached that research is not 'merely the sensation of knowledge in the making' but 'a sensing of our selves in the making' (Ellsworth, 2005, p. 1). Before introducing autopsychography, we summarise the differences between the four self-narrative approaches in Table 1.

\begin{tabular}{|c|c|c|c|}
\hline $\begin{array}{l}\text { Self-Narrative } \\
\text { Approaches }\end{array}$ & $\begin{array}{l}\text { Main } \\
\text { Disciplinary/Methodo } \\
\text {-logical Perspective }\end{array}$ & $\begin{array}{l}\text { Ways of Collecting / } \\
\text { Creating Stories }\end{array}$ & $\begin{array}{l}\text { Meaning of 'Self' and } \\
\text { the role(s) of } \\
\text { researchers }\end{array}$ \\
\hline Autoethnography & Cultural Anthropology & $\begin{array}{l}\text { Ethnographic research } \\
\text { (e.g. field notes) }\end{array}$ & \multirow{2}{*}{$\begin{array}{l}\text { Researchers creating } \\
\text { narratives about their } \\
\text { own personal }\end{array}$} \\
\hline Self-Portraiture & Education; Art & Participants & \\
\hline Life Story Approach & $\begin{array}{l}\text { Psychology (Individual } \\
\text { Psychology) }\end{array}$ & $\begin{array}{l}\text { Interview in which } \\
\text { participants tell their } \\
\text { stories in oral forms }\end{array}$ & \multirow{2}{*}{$\begin{array}{l}\text { Researchers creating } \\
\text { stories about } \\
\text { participants' selves }\end{array}$} \\
\hline Neo-Narrative & Education & $\begin{array}{l}\text { Participants } \\
\text { responding to } \\
\text { researchers' questions } \\
\text { (often in written }\end{array}$ & \\
\hline
\end{tabular}


Table 1. Distinctions between Four Self-Narrative Approaches

\section{Autopsychography}

The composition of the term autopsychography is similar to that of autobiography and autoethnography: auto- refers to 'self', 'of one's own'; -graphy as writing; and -psycho- is applied here to indicate its connection with psychology, as opposed to perspectives from cultural anthropology or sociology. By proposing autopsychography, we want to prioritise the shaping of the creative paths to recreate lived experience over simply reporting 'what happened', echoing Virginia Woolf's (2002) observation that one of the memoir writers' difficulties lies in their failure of 'leav[ing] out the person to whom things happened' (p. 79). Autopsychography lays emphasis on the psychological journey of the writer/creator/researcher when constructing 'stories' about the self and considers selfreflection on the experiences of self as an essential element of human condition.

To some extent, autopsychography shares some commonalities with autoethnography, though the two self-narrative approaches have subtle as well as more fundamental differences (please refer to Table 2). While autoethnography aims at exploring culture through self, autopsychography foregrounds self and positions culture as integral to self rather than as the context where the self is situated. In other words, autoethnographic research treats 'self' as the medium and instrument for research whereas autopsychography celebrates the multidimensionality of 'self' and values the process-oriented reflective nature of creating stories about and by the 'self'. To further underscore the distinctive features of autopsychography, we now discuss its four major theoretical underpinnings. 


\begin{tabular}{|c|c|c|c|}
\hline & & Autopsychography & Autoethnography \\
\hline \multirow{4}{*}{\multicolumn{2}{|c|}{ Commonalities }} & \multicolumn{2}{|c|}{ Acknowledging the role of subjective experience } \\
\hline & & \multicolumn{2}{|c|}{$\begin{array}{l}\text { Reliance on autobiographical materials (personal storytelling as the } \\
\text { main research instrument) }\end{array}$} \\
\hline & & \multicolumn{2}{|c|}{ Self-reflective nature } \\
\hline & & \multicolumn{2}{|c|}{ Embracing creative ways of 'forming' and 'representing' stories } \\
\hline \multirow{4}{*}{ Differences } & $\begin{array}{l}\text { Disciplinary } \\
\text { Influence }\end{array}$ & Humanistic Psychology & Cultural Anthropology \\
\hline & Perspective & Heuristic & Critical/interpretive/evocative \\
\hline & $\begin{array}{l}\text { Methodological } \\
\text { Core }\end{array}$ & $\begin{array}{l}\text { Psychological journey of a } \\
\text { person }\end{array}$ & $\begin{array}{l}\text { Connection between the } \\
\text { personal and the cultural }\end{array}$ \\
\hline & Emphasis & Personal change and growth & Cultural features \\
\hline
\end{tabular}

Table 2. Autopsychography VS. Autoethnography

\section{Humanistic Psychological Perspectives and the Heuristic Lens}

The distinctiveness of autopsychography lies in the infix -psycho-, which is applied not in its literal sense as 'spirit' and 'soul', but with an implication of its connection with the discipline of psychology. The dominant perspective that we adopt is that of humanistic psychology which, as opposed to the behavioristic and psychoanalytic frameworks, approaches the human being as the integrated person, or the whole person (Murray, 1938). With the aim of inquiring into 'what it means to be fully human' and 'assist[ing] humans in reaching full humanness' (Moss, 2011, p. 5), the two major methodological approaches of 
humanistic psychology are : 1) the application of personal documents (Allport, 1942; James, 1902/1982; Maslow, 1954/1987); and 2) a reflexive examination of the role of the 'psychologist', the 'psychoanalyst', or the 'researcher', recognising that researchers 'can understand human beings only by means of his own humanity’ (Bonner, 1967, p. 62).

Rooted in humanistic psychology, autopsychography aligns with a heuristic lens. In heuristic studies, the whole process (from selecting the research topic to undertaking research and to synthesising and reporting the study) is informed by the researcher's personal experience. The heuristic lens is thus well suited to the type of research where personal experience of the researcher is both the departure point and the frame of reference. Researchers who adopt a heuristic approach do not act 'in a detached matter', but 'in an integrative, living form [...] being involved, committed, interested, concerned' (Moustakas, 1967, p. 104).

\section{An Ethic of Caring}

Beyond all the basic ethical principles, autopsychography attaches to an ethic of 'caring', which is relational and positions care as virtue (Noddings, 2003/2005). This ethical stance implies that the researcher exhibits genuine interest and attentiveness towards the issue that s/he is studying. 'Caring' does not only mean the caring of others as researchers, it can also be applied to studies where we reflect on our own experience that involves 'self-other' relationship. Noddings (2003/2005) argues that '[t]he living other is more important than any theory' (p. xix, original emphasis). We want to suggest as well that the living self is more important than any theory. Autopsychography prioritises self-probing storytelling about 'self' over the urge to theorise. And when it comes to research initiatives that are predominantly centred around personal experience, autopsychography can be an original path along which the researcher probes into his/her psychological journey through self-reflection. 


\section{Emphasis on Growth and Change}

As our discussion of autopsychography is situated in the context of education research, we want to underline the two main characteristics of autopsychography informed by a Deweyan perspective. Dewey distinguishes educative experience from mis-educative experience, and he raises two major principles of educative experience: continuity and interaction. The principle of continuity is based on 'growth' in physical, intellectual and moral dimensions (Dewey, 1938/1998, p. 28) and the kind of growth that feeds into educative experience needs to be led into the direction towards continuing growth. This is connected to the principle of interaction since experience is based on interactions between objective and internal conditions (Dewey, 1938/1998, pp. 38-39). Moreover, the path of growth is paved with change. One of the advantages of autopsychography is its potential of revealing 'growth' and 'change' through prolonged and attentive self-reflection. The creation of autopsychography needs to 'depict people as poised for change' (Josselson, 1995, p. 42) by 'perch[ing] in the present, gazing backwards into the past while poised ready for flight into the future' (Abbs, 1974, p.7).

\section{Arts-Informed Features}

In line with the above theoretical stances, autopsychography entails an arts-informed approach, recognising that textual forms are not always the best approach to reflect on and reenact lived experience. Arts-informed approaches open up possibilities for autopsychographic research to be conducted and presented in diverse forms.

The idea of arts-informed inquiry can be traced to arts based research, as 'a vehicle through which the expressive qualities of an artistically crafted form can come to express meaning and significance (Barone \& Eisner, 2011, p. xiii). It also hints towards research that recognises the triad of knowing (theoria), doing (praxis), and making (poesis) (Irwin, 2004, p. 27; Irwin \& Springgay, 2008, pp. xxiii-xxiv). While we have used the suffix 'graphy', our 
vision of autopsychography encompasses forms other than 'writing'. It is possible, for example, to create visual autopsychography when visual materials are the main medium/instrument to narrate the growth of the 'self' (Hickman, 2013).

\section{An Example: Yanyue's Post Submission Experience}

We want to illustrate how autopyschography can be pursued in real practice by presenting the following autopsychographic study, through which Yanyue explores a doctoral student's experience during the last phases of $\mathrm{PhD}$ research. Given the concern of this paper, emphasis will be laid more on the method than on the outcome.

After submitting softbound copies of her doctoral thesis for examination, Yanyue decided to examine her everyday experience during this 'post submission' period. The topic reflects Yanyue's real-life situation as a $\mathrm{PhD}$ student in a British university. Similar to most universities in the UK, the last stage of doctoral study at Yanyue's institution mainly consists of three steps, as shown in Figure 2.

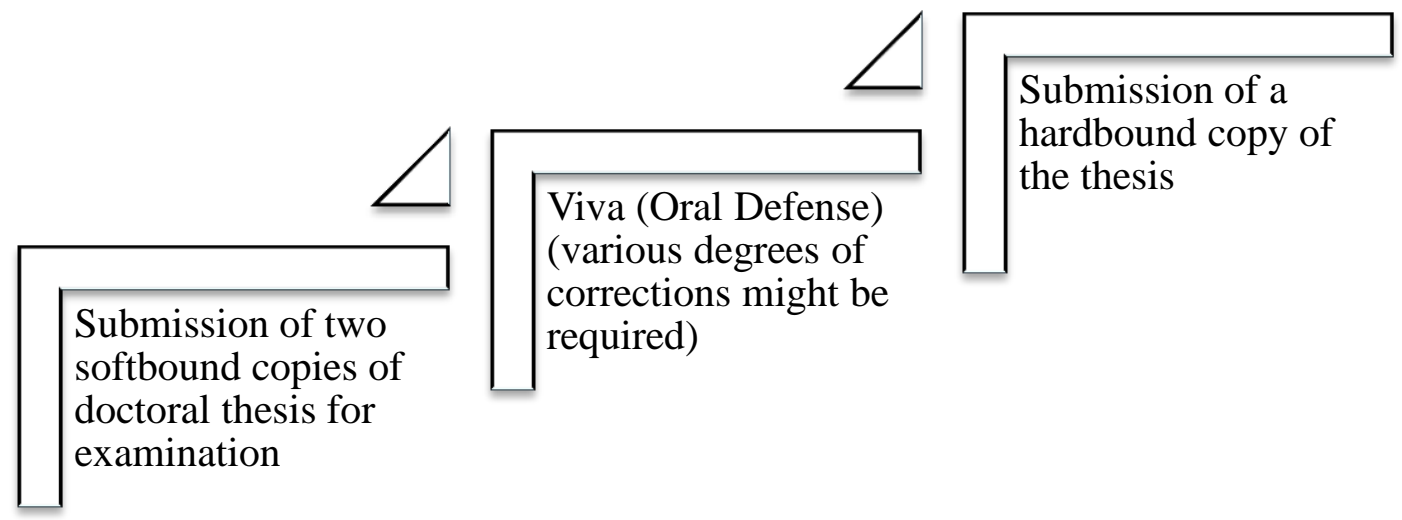

Figure 2. Last Three Phases of Doctoral Study at Yanyue's Institution 
Only after a hard bound copy of the thesis is submitted can a PhD candidate be awarded the doctoral degree, and the length of time between these steps can vary from one person to another. In Yanyue's case, she submitted her softbound copies on March $4^{\text {th }} 2015$ and completed her viva on May $26^{\text {th }} 2015$. The autopsychographic study is based on her reflection of her experience during that period.

The topic is also selected considering the lack of research in this particular area. Research about the final stages of doctoral studies usually focuses on PhD students' employment skills, choices of career, and their own perceptions of the doctoral experience, sometimes coupled with an intention to examine the accountability of higher education institutions and doctoral training. Such studies often draw on quantitative data acquired through surveys (Harman, 2010; Manathunga, Pitt, \& Critchley, 2009; Neumann \& Tan, 2011; Platow, 2012). When it comes to studies on international PhD students' experience, the focus is often set on their overall experience, including their sense of security (ForbesMewett \& Nyland, 2008) and loneliness (Sawir, Marginson, Deumert, Nyland, \& Ramia, 2008), their financial support, course experience and career plans (Harman, 2003); their perception of the whole experience (Trice \& Yoo, 2007); and their experience of adjusting their academic practices after returning home (Robinson-Pant, 2009). Scarce attention has been given to in-depth research into the last stages of the doctoral journey, which to Yanyue's knowledge (from her own experience and her communication with other $\mathrm{PhD}$ students), can be imbued with stress, anxiety and uncertainty. It is likely that international doctoral students find themselves more vulnerable when confronting such emotions as some of them might need to deal with change of geographical locations once again (e.g., returning to their home country, or travel to wherever the next job takes them). 


\section{'Oral Diary’: Talking and Listening to Oneself}

In Yanyue's autopsychographic study, she trialled one specific strategy, 'oral diary', which she defines as a series of recorded accounts of one's reflections in oral forms on a regular basis over a certain period of time. This form of data creation fits well with the nature of autopsychographic study, as it creates a space for self-reflection without alerting oneself too much to the intentionality of such acts.

Writing and speaking are the two main sources of verbal accounts, and in social science research, the former is often adopted by researchers whereas the latter is often used when working with participants. During research interviews, for instance, researchers hope to encourage participants to speak about their opinions and feelings in relation to a particular topic or certain aspects of their experience. The recorded spoken accounts are to be edited and analysed by the researcher. In Figure 3, we roughly illustrate how interview data is usually processed in research. One major step is 'transcribing', as researchers turn the verbal content in an oral form into a textual form, which is then fed into a written report. Though on some occasions, researchers would take into account other non-verbal features (e.g., gesture, facial expression), verbal information almost always dominate researchers' collection and analysis of interview data. 


\section{$\circ \circ 0 \circ \%$ \\ $\stackrel{0}{\circ} \circ 0^{\circ} \circ 0^{\circ}$}

(oral conversation)

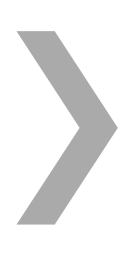

Transcribing

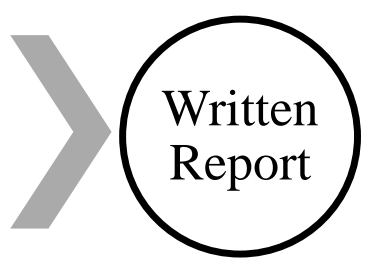

('oral' to 'textual')

Figure 3. Using Interview in Research

While participants often express their ideas and have their voice heard through oral forms, researchers often communicate their research in written forms. In the academic world, the latter seems to receive more credits than the former, as reflected in scholars' pressure to produce publications (which, in comparison to conference presentations, tends to bring more academic reputation). This hierarchy of verbal accounts has great influence on the way research is conducted, presented and evaluated. Written accounts are also the main form of establishing reflexivity into research, as represented by memos and field notes.

Practicality might be another reason why the oral form is seldom used by researchers themselves. While interview mirrors the format of everyday conversations, researchers can find it hard and unnatural to express their own thoughts in oral accounts when left on their own. Some scholars have, however, experimented with recording their thoughts in oral forms. One example is Choi's (2010) autoethnographic study on museum visitors' narrative construction in which she draws on her own monologue recorded during her museum visits as part of the research data. In Yanyue's autopsychographic study, she deliberately stretches 
the role of oral accounts and relies on 'oral diary' as the main source of data. She calls it 'oral diary' because the recorded accounts are mainly organised by date and each piece is a reflection on her daily life. During this autopsychographic exploration, eight recordings were produced between March $2^{\text {nd }}$ and May $26^{\text {th }} 2015$.

The major difficulty that Yanyue encountered when applying this method was the slight awkwardness of talking to herself and recording her own voice. Again, this might be influenced by the social norm of writing and speaking: writing is often regarded as individual's independent efforts whereas speaking is usually carried out in conversations. Monologue is not as common in real life as diary/blog writing. But as Yanyue gradually got used to this approach, she began to appreciate the merit of this oral form of expression and she found it liberating to talk about her daily life by herself. Later on, she even began to enjoy these moments of solitude and self-reflection. The eight recordings were saved on her electronic device (iPad) and it was one month after she made the last recording that she started to listen to her own accounts. From her experience of experimenting with 'oral diary', Yanyue has identified three of its distinctive features in comparison to written accounts :

- It allows one to capture random and fleeting thoughts that might get lost when using written forms;

- It often leaves traces of non-textual elements, such as tone and intonation;

- It requires one to engage with the sense of hearing when working with the audio data.

By allowing a temporal gap between creating oral diaries and listening to the recordings, Yanyue was able to listen to her own accounts with a sense of freshness. She also noted that unlike reading written documents, it was practically difficult to get an instant sense of the whole content. When listening to the recordings, Yanyue's attention was directed to details and nuances, and to both her emotional state and the content. While the original recordings are, to some degree, the most authentic and complete version of Yanyue's 
experience, they are not the ideal form for communicating Yanyue's post-submission experience. What then could Yanyue do with the recordings and in which forms could she present the 'essence' of her oral diaries?

\section{Found Poetry}

Echoing the exploratory nature of Yanyue's autopsychographic study and the characteristics of autopsychography, Yanyue decided to turn the oral diaries into a found poem that features her post-submission experience. When Yanyue was listening to each of the recordings, she did not choose to do a word for word transcription. While transcription is still much expected when it comes to audio recordings of oral accounts, Yanyue believes it is important for the researcher to carefully think about the purposes of transcription. With the aim of creating a found poem based on the recordings, Yanyue typed the phrases and expressions that touch upon her subjective feelings and those descriptions with particular relevance to this period of life. The key words and phrases then became the source of her poem.

Using found poetry to analyse interviews and present research has been discussed by several researchers (Butler-Kisber, 2002; Cahnmann, 2003; Richardson, 1992). Richardson (1992) believes that poetry has the advantage of 'playing with connotative structures and literary devices to convey meanings; ... commend[ing] itself to multiple and open readings in ways conventional sociological prose does not' (p. 126). When researchers edit the interview transcriptions into found poems, they have much freedom to select and organise the original content and meanwhile they merge their own subjectivity into the poems.

The form of found poetry refers back to the arts-informed feature of autopsychography. Through artistic creation, one can strive to re-enact the often ineffable and ambiguous aspects of one's psychological state. In this autopsychographic exploration, the process of creating a found poem initiates a flow that links acts of recording oral diaries, 
listening to one's own reflections, extracting key messages, and constructing a poem. These interconnected steps constitute a multi-layered reflective space, and the different patterns of verbal expressions help to crystalise parts of the lived experience. Yanyue wrote the following found poem entitled 'Nothing has changed a lot really' based on the eight oral diaries about her post-submission experience.

\section{Nothing Has Changed A Lot Really}

3 years and a half

Doing this PhD

Now, thesis submitted

Now, I look at the calendar

Identifying which point I am at

Nothing has changed a lot really

Still in research mode

Carrying on this routine of writing--

Working on a few papers

And application material for jobs

Nothing has changed a lot really

I get really bored

By such computer-bound deskwork

Tension grows in my right hand

A slight syndrome from typing on the keyboard

Nothing has changed a lot really

Luckily, there are distractions

For a difference--

Practising calligraphy

Finding a peaceful mind

Doing body stretches

Getting the connection back

Delivering supervision

Gaining helpful experience

Making radio shows

Feeling a sense of achievement

And disposing some of the belongings

Makes it neat and clean

Makes it psychologically lighter

Makes it a simple way of living 
Perhaps it is a sign

A sign that I am really leaving here

Nothing has changed a lot really

But it will...

What comes next?

After passing the viva

After finding the job

Not yet

Now I am moving

Between multiple worlds every day

Torn by different expectations

All too complicated

Sometimes totally lost, anxious and frustrated

What is the job?

Where is the job?

A bleak picture really

No idea of the next stop

Sometimes a little bit trapped

Longing for a change of environment

For the journey home

I really don't care about

Filling this blank stage on my $C V$

I have the right to have a rest

Just living this moment

I have the right to take some time off

Not doing anything

Calm down

Be patient

Take it easy

Don't worry

about unnecessary worries

All the uncertainty

Is just the reality

Just the beauty of life

Nothing has changed a lot really

The found poem partly reflects the main features of autopsychography and its theoretical stances. One discernible character, as manifested by the poem, is its authenticity. When transforming the oral diaries into the found poem, Yanyue kept most of the words and 
phrases verbatim. For example, the title 'Nothing has changed a lot really' might not be grammatically appropriate, but through listening to the recordings, Yanyue felt that the phrase captures the overall theme of her experience during that period and her original reflections upon her own psychological state.

The found poem creates a sense of rhythm, and reveals the growth and change that Yanyue experienced. By trying different ways of relaxing and challenging herself, Yanyue was able to explore other dimensions of her self in non-academic activities. While she was mainly overwhelmed by a sense of uncertainty, this transitional stage offered her opportunities to pay special attention to her physical and mental health. After struggling with a sense of uneasiness brought by an unclear future prospect, she began to appreciate this ambiguous state of life.

What Yanyue also noticed while listening to her recordings was that she frequently talked about what she had been doing and how she felt about the tasks and events that she was engaged in. Expressions of her sentiments and comments of daily trivialities are mingled together. The form of 'oral diary' does not impose a predefined structure, thus giving Yanyue much freedom to explore what she cared about and what matters to her during this transitional period. This liberating framework echoes the heuristic lens and the ethic of caring mentioned above.

\section{Summary}

In this paper, we started by examining the fundamental differences among selfnarrative approaches, which we identify as the different implications of the 'self' and the different positioning of researchers. We looked at the two forms of autoethnography and classified self-narrative into three types, marked by the different connotations of the self and the relation between the researcher and the storyteller. By proposing 'autopsychography' as a form of self-narrative inquiry, we emphasised the creative process of forming self-narrative 
and prioritise the exploration of one's psychological journey over the reporting of past events. We have explained the four major theoretical underpinnings of autopsychography: 1) humanistic psychology and heuristic lens; 2) an ethic of caring; 3) emphasis on growth and change; and 4) arts-informed features. In addition, we articulated the subtle differences between autopsychography and autoethnography.

The autopsychographic study here is based on Yanyue's exploration of her postsubmission experience, in which she experiments with 'oral diaries' to create data and found poetry to present the final outcome. It is worth noting that English is Yanyue's second language ${ }^{1}$. She chose to use English not only for practicality and her confidence of applying English in such circumstances, but also because it would be difficult to retain the rhythm and subtleties when translating poetic language. We believe that the selection of language does, to a certain extent, influence the way one expresses oneself when carrying out autopsychographic research, which warrants further research attention.

Methodologically, autopsychography has the potential of opening up new avenues when it comes to under-researched topics pertaining to personal experience. One possible prototype that emerges from this study is a creative path that begins with a series of spontaneous creations in expressive forms and evolves into a reflective and synthesised recreation. Our example can be adjusted when other arts-informed approaches are taken, for instance, a photo montage based on a selection of photos taken during a certain period of time; a 3-D collage based on sketches and visual creations created across time; or a piece of music based on improvisational musical snippets.

In future studies, autopsychography can applied be in a collaborative study where researchers work with other participants to co-design, co-conduct and co-create a piece of autopsychography.

\footnotetext{
${ }^{1}$ Yanyue's mother tongue is Mandarin Chinese.
} 


\section{References}

Abbs, P. (1974). Autobiography in education: an introduction to the subjective discipline of autobiography and of its central place in the education of teachers, with a selection of passages from a variety of autobiographies, including those written by students. London, England: Heinemann Educational.

Alexander, D. (1992). Discussion documents as neonarratives. Journal of Education Policy, 7(1), 71-78.

Alexander, D., \& Galbraith, P. (1997). Stories of transition: From students to teachers. Queensland Journal of Educational Research, 13(1), 17-32. Retrieved from http://education.curtin.edu.au/iier/qjer/qjer13/alexander.html

Allport, G. W. (1942). The use of personal documents in psychological science (Bulletin No. 49), prepared for the Committee on the Appraisal of Research). New York, NY: Social Science Council.

Atkinson, R. (1998). The life story interview. Thousand Oaks, CA; London, England: Sage.

Barone, T., \& Eisner, E. W. (2011). Arts based research. London, England: SAGE.

Bonner, H. (1967). The proactive personality. In J. F. T. Bugental (Ed.), Challenges of humanistic psychology (pp. 61-66). New York, NY: McGraw-Hill.

Butler-Kisber, L. (2002). Artful portrayals in qualitative inquiry: The road to found poetry and beyond. The Alberta Journal of Educational Research, XLVIII(3), 229-239.

Cahnmann, M. (2003). The craft, practice and possibility of poetry in educational research. Educational Research, 32(3), 29-36.

Choi, S. (2010). Making the negotiation between narratives of museum and a visitor: Empowering a visitor through narrative-making (Doctoral dissertation, The Pennsylvania State University). Retrieved from http://etda.libraries.psu.edu/paper/10607/6297 
Dewey, J. (1998). Experience and education (60th anniversary ed.). West Lafayette, IN: Kappa Delta Pi. (Original work published in 1938).

Ellis, C. (2004). The Ethnographic I: A methodological novel about autoethnography. Walnut Creek, CA: AltaMira Press.

Ellsworth, E. (2005). Places of learning: Media, architecture, pedagogy. New York, NY: Routledge.

Forbes-Mewett, H., \& Nyland, C. (2008). Cultural diversity, relocation, and the security of international students at an international university. Journal of Studies in International Education, 12(2), 181-203.

Harman, G. (2010). Producing PhD graduates in Australia for the knowledge economy. Higher Education Research \& Development, 21(2), 179-190.

Harman, G. (2003). International PhD students in Australian universities: financial support, course experience and career plans. International Journal of Educational Development, 23(3), 339-351.

Hickman, R. D. (2011). The art and craft of pedagogy: Portraits of effective teachers. London, England: Continuum.

Hickman, R. D. (2013, July). A personal journey through art education 1956-2013. Keynote Speech presented at the InSEA European Regional Congress, Canterbury, England. Irwin, R. L. (2004). A/r/tography: A metonymic metissage. In R. L. Irwin \& A. de Cosson (Eds.), A/r/tography: Rendering self through arts-based living inquiry (pp. 27-38). Vancouver, Canada: Pacific Educational Press.

Irwin, R. L., \& Springgay, S. (2008). A/r/tography as practice-based research. In S. Springgay, R. L. Irwin, C. Leggo \& P. Gouzouasis (Eds.), Being with a/r/tography (pp. xix-xxxiii). Rotterdam, The Netherlands: Sense Publishers. 
James, W. (1982). The varieties of religious experience: A study in human nature. New York, NY: Penguin. (Original work published 1902)

Jones, S. H., Adams, T. E., \& Ellis, C. (2013). Introduction: Coming to know autoethnography as more than a method. In S. L. Holman Jones, T. E. Adams, \& C. Ellis (Eds.), Handbook of autoethnography (pp. 17-47). Walnut Creek, CA: California Left Coast Press.

Josselson, R. (1995). Imagining the real: Empathy, narrative, and the dialogic self. In R. Josselson \& A. Lieblich (Eds.), Interpreting experience: The narrative study of lives (pp. 27-44). Thousand Oaks, CA; London, England: Sage.

Leggo, C. (2008). Autobiography: Researching our lives and living our research. In S. Springgay (Ed.), A/r/tography as practice-based research (pp. 3-23). Rotterdam, The Netherlands: Sense Publishers.

Manathunga, C., Pitt, R., \& Critchley, C. (2009). Graduate attribute development and employment outcomes: Tracking PhD graduates. Assessment \& Evaluation in Higher Education, 34(1), 91-103.

Maslow, A. H. (1987). Motivation and personality. New York, NY: Van Nostrand Reinhold. (Original work published 1954)

Mishler, E.G. (1999). Storylines: Craft artists' narratives of identity. Cambridge, MA: Harvard University Press.

Moss, D. (2001). The roots and genealogy of humanistic psychology. In K. J. Schneider, J. F. T. Bugental \& J. F. Pierson (Eds.), The handbook of humanistic psychology: Leading edges in theory, research, and practice (pp. 5-20). Thousand Oaks, CA; London, England: Sage Publications.

Moustakas, C. (1967). Heuristic research. In J. F. T. Bugental (Ed.), Challenges of humanistic psychology (pp. 101-107). New York, NY: McGraw-Hill. 
Murray, H. A. (1938). Explorations in personality; A clinical and experimental study of fifty men of college age. New York, NY; London, England: Oxford university press.

Neumann, R., \& Tan, K. K. (2011). From PhD to initial employment: The doctorate in a knowledge economy. Studies in Higher Education, 36(5), 601-614.

Noddings, N. (2005). The challenge to care in schools: An alternative approach to education (2nd ed.). New York, NY; London, England: Teachers College Press. (Original work published in 2003).

Platow, M. J. (2012). PhD experience and subsequent outcomes: A look at self-perceptions of acquired graduate attributes and supervisor support. Studies in Higher Education, $37(1), 103-118$.

Polkinghorne, D. (1988). Narrative knowing and the human sciences. Albany, NY: State University of New York Press.

Reed-Danahay, D. (1997). Introduction. In D. Reed-Danahay (Ed.), Auto/ethnography: Rewriting the self and the social (pp. 1-17). Oxford, England: Berg.

Richardson, L. (1992). The consequences of poetic representation. In C. Ellis \& M. C. Flaherty (Eds.), Investigating subjectivity: Research on lived experience (pp. 125137). Newbury Park, CA: Sage Publications.

Robinson-Pant, A. (2009). Changing academies: Exploring international PhD students' perspectives on 'host' and 'home' universities. Higher Education Research \& Development, 28(4), 417-429.

Sawir, E., Marginson, S., Deumert, A., Nyland, C., \& Ramia, G. (2008). Loneliness and international students: An Australian study. Journal of Studies in International Education, 12(2), 148-180. 
Stewart, R. (2008). Constructing neo-narratives: A pluralistic approach to research. In R.

Hickman (Ed.) Research in art and design education: Issues and exemplars. Bristol, England: Intellect.

Trice, A. G. \& Yoo, J.E. (2007). International graduate students' perceptions of their academic experience. Journal of Research in International Education, 6(1), 41-66.

Woolf, V. (2002). Moments of being. London, England: Pimlico. 
